\title{
Escherichia coli inactivation kinetics in anaerobic digestion of dairy manure under moderate, mesophilic and thermophilic temperatures
}

\author{
Pramod K Pandey ${ }^{*}$ and Michelle L Soupir
}

\begin{abstract}
Batch anaerobic digestion experiments using dairy manure as feedstocks were performed at moderate $\left(25^{\circ} \mathrm{C}\right)$, mesophilic $\left(37^{\circ} \mathrm{C}\right)$, and thermophilic $\left(52.5^{\circ} \mathrm{C}\right)$ temperatures to understand $E$. coli, an indicator organism for pathogens, inactivation in dairy manure. Incubation periods at 25,37 , and $52.5^{\circ} \mathrm{C}$, were 61,41 , and 28 days respectively. Results were used to develop models for predicting $E$. coli inactivation and survival in anaerobic digestion. For modeling we used the decay of $E$. coli at each temperature to calculate the first-order inactivation rate coefficients, and these rates were used to formulate the time - temperature - E. coli survival relationships. We found the inactivation rate coefficient at $52.5^{\circ} \mathrm{C}$ was 17 and 15 times larger than the inactivation rate coefficients at 25 and $37^{\circ} \mathrm{C}$, respectively. Decimal reduction times $\left(\mathrm{D}_{10}\right.$; time to achieve one log removal) at 25,37 , and $52.5^{\circ} \mathrm{C}$, were 9 -10, 7 - 8 days, and $<1$ day, respectively. The Arrhenius correlation between inactivation rate coefficients and temperatures over the range $25-52.5^{\circ} \mathrm{C}$ was developed to understand the impacts of temperature on $E$. coli inactivation rate. Using this correlation, the time - temperature - E. coli survival relationships were derived. Besides E. coli inactivation, impacts of temperature on biogas production, methane content, $\mathrm{pH}$ change, ORP, and solid reduction were also studied. At higher temperatures, biogas production and methane content was greater than that at low temperatures. While at thermophilic temperature $\mathrm{pH}$ was increased, at mesophilic and moderate temperatures $\mathrm{pH}$ were reduced over the incubation period. These results can be used to understand pathogen inactivation during anaerobic digestion of dairy manure, and impacts of temperatures on performance of anaerobic digesters treating dairy manure.
\end{abstract}

Keywords: E. coli, inactivation kinetic, dairy manure, anaerobic digestion, temperature

\section{Introduction}

In the United States, combined livestock production of cattle, swine, and sheep generates $49 \%$ of the total farm income, which is nearly 241 billion dollars (US Census Bureau 2010,). The practice of applying livestock manure to recycle waste to enhance crop yield is more than 4,000 years old, and this practice continues to reduce farm fertilization costs in the developing as well as the developed world (WHO 2010,; USEPA 2010,). However, land application of manure can damage environmental ecosystems (USEPA, 2010,) and create a risk to human health if not applied properly. Runoff from fields where manure has been applied can be a source of pathogen

\footnotetext{
* Correspondence: pkpandey@iastate.edu

Agricultural and Biosystems Engineering Department, lowa State University,
} Ames, 50011, USA contamination in ambient water bodies including streams lakes and reservoirs and groundwater systems (Brennan et al. 2010,; Gerba and Smith 2005;; Mawdsley et al.1995,; Pell 1997,; Tyrrel and Quinton 2003,; Unc and Goss 2004,), particularly if a rainfall event occurs soon after application (Soupir et al. 2006).

Manure can contain numerous pathogenic organisms that are associated with human diseases including salmonella, E. coli O157:H7, Yesinia, campylobacter, guardia, and cryptosporidium (Klein et al. 2010,; Létourneau et al. 2010,; Massé et al. 2010,; Ziemer et al. 2010,). Treating manure before land application can greatly reduce the number of viable pathogens, and various methods such as drying (Amin-Nayyeri et al. 2010,), composting (Maeda et al. 2010,), heat treatment (Shepherd Jr et al. 2010,), radiation treatment (Farag and

\section{SpringerOpen $^{\odot}$}

(c) 2011 Pandey and Soupir; licensee Springer. This is an Open Access article distributed under the terms of the Creative Commons Attribution License (http://creativecommons.org/licenses/by/2.0), which permits unrestricted use, distribution, and reproduction in any medium, provided the original work is properly cited. 
Mohamed 1999,; Sinton et al. 2007,), aerobic digestion (Bortone 2009,; Dumas et al. 2010,; Shen et al. 2010,), and anaerobic digestion (Aitken et al. 2005; Aitken et al. 2007,; Lang and Smith 2008,; Popat et al. 2010,; Sung and Santha 2003,; Wagner et al. 2009) are typically used. Of these, anaerobic digestion is crucial as it produces biogas, a source of energy, in addition to reducing pathogens.

The use of anaerobic digesters for biogas production and manure treatment is well established and has been implemented all over the world. A tremendous amount of research has been conducted on the anaerobic digestion process to enhance biogas production (Climent et al. 2007,; He et al. 2008,; Kim et al. 2010,; Pandey et al. 2010,; Yilmaz and Demirer 2008,; Zaher et al. 2008,), increase nutrient recovery (Banu et al. 2009,; Carrere et al. 2010,; Jin et al. 2009,; Novak et al. 2010,; Prapaspongsa et al. 2010,; Wang et al. 2010,), and reduce solids content (Forster-Carneiro et al. 2010,; Gilroyed et al. 2010,; Gong et al. 2010,; Riau et al. 2010,; Rubio-Loza and Noyola 2010).

Batch reactors are a useful tool to improve understanding of the outcomes of anaerobic digestion processes. Masse et al. (2010) evaluated efficiency of commercial-scale psychrophilic anaerobic digestion in sequencing batch reactors, operated at 7 or 14 days hydraulic retention time and $24^{\circ} \mathrm{C}$. The authors found that the concentrations of fecal coliforms, E. coli, Salmonella, Campylobacter spp., and Y. enterocolitica were reduced to undetectable levels in pig manure. Côté et al. (2006) found nearly complete reduction of total coliforms and $E$. coli by anaerobic digestion at $20^{\circ} \mathrm{C}$ for 20 days while Baert et al. (2010) observed a 4 log decrease of Murine Norovirus- 1 at 37 and $52^{\circ} \mathrm{C}$ after 13 and 7 days, respectively. Several studies have focused on pathogen inactivation in sludge anaerobic digestion at thermophilic temperatures to achieve Class A (complete pathogen inactivation) and Class B (incomplete pathogens removal) classification (Aitken et al. 2005; Popat et al. 2010,; Puchajda et al. 2006,; Smith et al. 2005,; Wagner et al. 2009,). For example, Shin et al. (2010), used the batch process to show decreases in bacteria $16 \mathrm{~S}$ rRNA gene concentrations and organic removal efficiency in anaerobic digestion of secondary sludge, while Aitken et al. (2005) measured the inactivation of vaccine - strain poliovirus and eggs from helminth Ascaris suum at temperatures from 49 to $55^{\circ} \mathrm{C}$ in biosolids. Popat et al. (2010) used the batch process to estimate the inactivation kinetics of Ascaris suum and poliovirus type 1 (PVS -1) at temperatures ranging from 51 to $56^{\circ} \mathrm{C}$. Despite previous studies to determine pathogen decay under anaerobic conditions, no information exists on the performance of anaerobic digestion in reducing pathogen concentrations in dairy manure.
Aitken et al. (2005), and Popat et al. (2010) provided important information about pathogen inactivation kinetics in anaerobic digestion. However, both of these studies are focused on anaerobic digestion of sludge obtained from municipal waste treatment facilities, and inactivation kinetics were determined at temperatures ranging from 49 to $56^{\circ} \mathrm{C}$ (thermophilic). Both studies emphasized the need for improving EPA's time - temperature relationships. Our objective is to determine the E. coli inactivation kinetics in dairy manure at moderate $\left(25^{\circ} \mathrm{C}\right)$, mesophilic $\left(37^{\circ} \mathrm{C}\right)$ and thermophilic $\left(52.5^{\circ} \mathrm{C}\right)$ temperatures, and use the inactivation kinetics at these temperatures to derive the time - temperature - survival relationship for calculating $E$. coli survival in anaerobic digesters treating dairy manure.

\section{Materials and methods \\ Anaerobic reactor setup}

Fresh manure was collected from Iowa State University's dairy facility 24 hours prior to the start of the experiment to prepare the feedstock for the anaerobic reactors. To prepare the feedstock, $0.498 \mathrm{~kg}$ of fresh manure was mixed thoroughly in $1,500 \mathrm{ml}$ of distilled water. Fibers and large solid particles in the manure were removed using a sieve with an $850 \mu \mathrm{m}$ opening (USA standard testing sieve, No 20, Fisher Scientific Company).

Experiments were conducted for moderate temperature, mesophilic temperature, and thermophilic temperature at 25,37 , and $52.5^{\circ} \mathrm{C}$, respectively. The moderate and mesophilic temperature experiments lasted 61 and 41 days respectively. Thermophilic experiments lasted for 28 days; however, E. coli was not detected after the fourth day of incubation. E. coli concentration was enumerated regularly; every 24 hours during the first two weeks for the moderate and mesophilic temperature experiments, and every 12 hours for the thermophilic experiment.

Each experiment included six anaerobic batch reactors, $250 \mathrm{ml}$ serum bottles (Scientific Instrument Services, NJ, US), for incubating the feedstock. One hundred fifty $\mathrm{ml}$ of feedstock was transferred into each reactor, and then the reactors were sealed with a rubber septum (Sigma-Aldrich, sleeve stopper, MW 09194, St. Louis, MO, US). Before starting each experiment, an anaerobic environment at the reactor's headspace were created. The reactors were placed in an orbital water bath shaker (New Brunswick Scientific, Classic Series C7, 400768741, Edison, New Jersey, USA). During each experiment, the water bath shaker speed was maintained at $150 \mathrm{rpm}$. For analyzing E. coli, we collected incubated liquid slurry from three out of six reactors (randomly selected) using a $35 \mathrm{ml}$ gas tight glass syringe (Micro Mate, Popper \& Sons Inc, New Hyde Park, NY). The 
biogas at each reactor was measured using a $35 \mathrm{ml}$ gas tight glass syringe (Micro - Mate, Popper \& Sons Inc, New Hyde Park, NY). To measure the biogas, the needle of the syringe was inserted into the septum, and the gas pressure in the bottle displaced the syringe plunger. The displaced volume indicated the amount of biogas produced, which was analyzed for $\mathrm{CH}_{4}$ content.

\section{$E$. coli enumeration}

To enumerate E. coli concentrations in the incubated slurry, we used membrane filtration techniques using standard modified mTEC agar (growth media) (APHA, 1999). The liquid samples collected from the reactors were stored at $4^{\circ} \mathrm{C}$ immediately. To enumerate $E$. coli numbers, sample processing was performed within 24 hours of sample collection. The samples were serially diluted, and the diluted samples were filtered through $0.45 \mu \mathrm{m}$ membrane filters (Millipore, FOEA 22910, HAWG047S, France). Membrane filters placed in petri dish with growth media were incubated at $44.5 \pm 0.2^{\circ} \mathrm{C}$ for 24 hours. The red or magenta $E$. coli colonies grown in petri dish after incubation were enumerated. All analysis was performed in triplicate. Besides E. coli enumeration, we tested total solids (TS), volatile solids (VS), total nitrogen $(\mathrm{TN})$, total phosphorous (TP), and total organic carbon (TOC) using standard methods (APHA, 1999).

\section{Data analysis}

E. coli concentrations were averaged among the three replicates and used to estimate the first order kinetics:

$$
C / C_{0}=e^{-k \cdot t}
$$

where $C_{O}$ is the initial $E$. coli concentration $(\mathrm{CFU} / \mathrm{ml})$, $C$ is the concentration $(\mathrm{CFU} / \mathrm{ml})$ at time $t, k$ is first order inactivation rate coefficient (1/day) and $t$ is time (day). The value of $k$ (slope of regression) was estimated by liner regression between $\ln$ of $E$. coli concentration $(\mathrm{CFU} / \mathrm{ml})$ and time (day).

The effect of temperatures (moderate, mesophilic, and thermophilic) on the inactivation rate coefficient was estimated by the Arrhenius equation.

$$
k(T)=A e^{-\left(E_{a} / R T\right)}
$$

where $k(T)$ is the inactivation rate coefficient as a function of temperature for a given temperature and $A$ is a pre-exponential factor, a constant for a given reaction. The $E_{a}$ is the activation energy (Joules/mol). The activation energy describes the influence of temperature on the magnitude of the first order reaction rate constant. The $R$ is the gas constant (8.314472 Joules/mol K) and $T$ is temperature $(\mathrm{K})$. The $E a / R$ (slope of the regression line) and $A$ (y-intercept) of equation 2 were obtained by plotting $\ln k(T)$ and $1 / T$. Decimal reduction time $\left(\mathrm{D}_{10}\right)$, time required to inactivate $90 \%$ of $E$. coli, was calculated at each temperatures using log of E. coli (CFU/ml) (Murphy 2002).

\section{Results}

Results of E. coli inactivation at 25 (moderate), 37 (mesophilic), and $52.5^{\circ} \mathrm{C}$ (thermophilic) temperatures are shown in Figures 1a, b, and 1c, respectively. E. coli concentrations are plotted as logarithmic values to easily observe reduction over time. The inactivation was relatively high at $52.5^{\circ} \mathrm{C}$, with inactivation rate coefficients 17 and 15 times greater than that of at 25 and $37^{\circ} \mathrm{C}$ experiments, respectively. At $25^{\circ} \mathrm{C}$, greater than a six $\log$ reduction was observed during the 60 day incubation period; while, at $37^{\circ} \mathrm{C}$ approximately a six log reduction was obtained during 41 days of incubation. At $52.5^{\circ} \mathrm{C}$ greater than seven log reductions was obtained in 3.5 days; at this temperature after 4 days, E. coli reached to undetectable levels.

The characteristics of feedstock used in anaerobic digestion are shown in Table 1 . The initial E. coli concentrations in feed stocks were $6.5 \times 10^{7}, 1.85 \times 10^{7}, 2.5$ $\times 10^{7} \mathrm{CFU} / \mathrm{ml}$ for the experiment at 25,37 , and $52.5^{\circ} \mathrm{C}$, respectively. Total organic content (TOC) for these feedstocks were 4500, 4170, and $3900 \mathrm{mg} / \mathrm{L}$, respectively. While total nitrogen (TN) concentrations were 489, 390, $522 \mathrm{mg} / \mathrm{L}$, total phosphorous concentrations were 153, 333, and $243 \mathrm{mg} / \mathrm{L}$, respectively (Table 1). The inactivation rate constants, $R^{2}$ of linear regression, $T_{c}$ (time required for complete inactivation, and decimal reduction time $\left(\mathrm{D}_{10}\right)$ are shown in Table 2. E. coli survived the longest in moderate temperature ( $>60$ days), and decayed quickly under thermophilic conditions $(<4$ days). Compared to the moderate temperature experiment $\left(R^{2}=0.81\right)$, better results were achieved for mesophilic and thermophilic experiments $\left(\mathrm{R}^{2}>0.90\right)$. The $T_{c}$ at moderate and mesophilic temperatures were greater than 60 and 40 days, respectively; the $T_{c}$ at thermophilic temperature was less than 4 days (Table 2). During the first 10 days at moderate temperature, E. coli inactivation trend deviated from the expected first-order kinetics, which was relatively consistent after day 10 of incubation.

To model the impacts of temperature on the inactivation rate coefficients, we used the Arrhenius equation. Figure 2 shows the plot between $\ln k(T)$ and $1 / T$. The $R^{2}$ of linear regression between $\ln k(T)$ and $1 / T$ was 0.82 . The slope of the fitted line corresponds to activation energy of $84.9 \mathrm{~kJ} \mathrm{~mol}^{-1}$.

Figure 3 shows $E$. coli survival with time for temperatures ranging from $22-62^{\circ} \mathrm{C}$. The value of $A$ in the Equation 2 was adjusted (we used $\mathrm{A}=2.83 \times 10^{13}$ ) until 

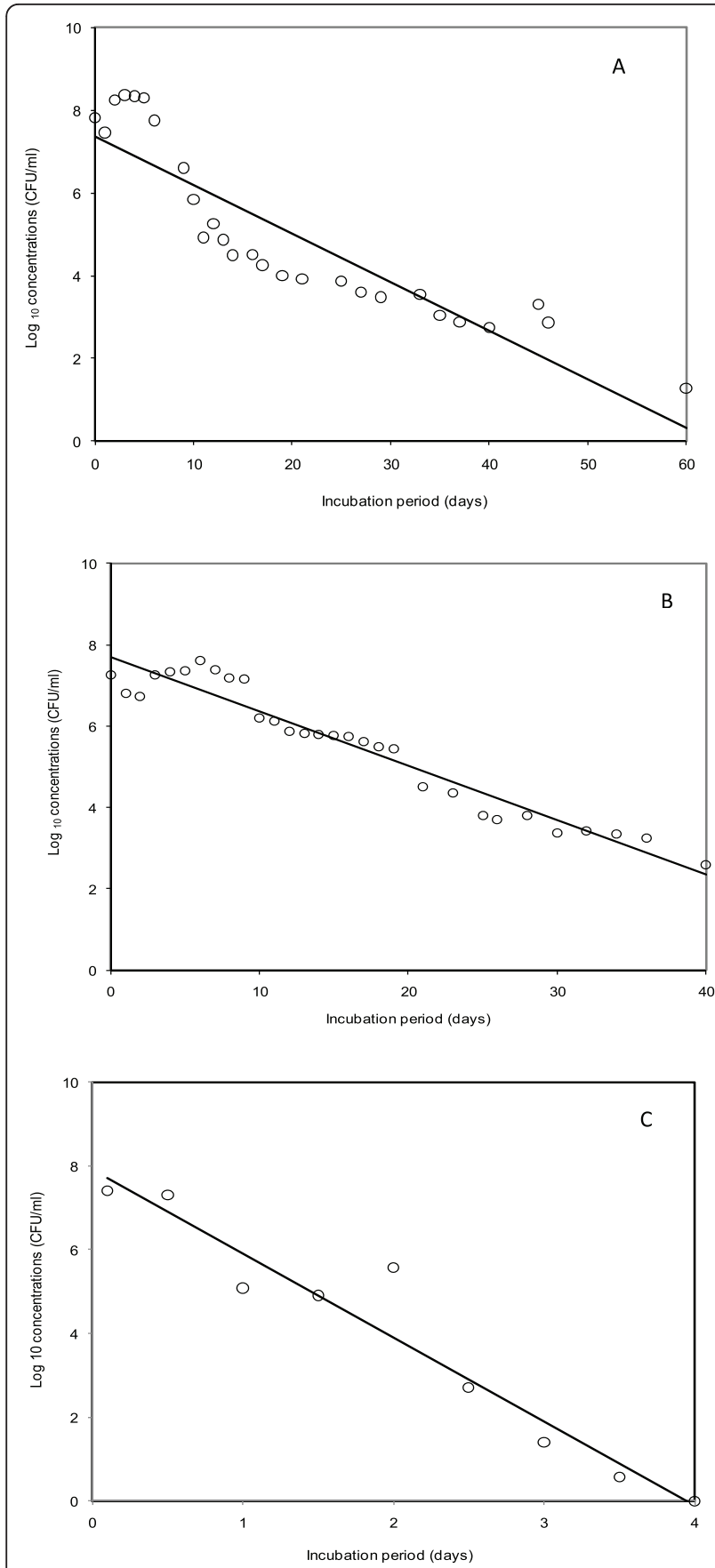

Figure 1 Variations in $E$. coli concentrations with incubation periods: (A) $25^{\circ} \mathrm{C}$; (B) $37^{\circ} \mathrm{C}$; (C) $52.5^{\circ} \mathrm{C}$. The plot shows $\log _{10}$ of $E$. coli concentrations (hollow circle) and regression line (solid black).

the predicted survival percentages at 25,37 , and $52.5^{\circ} \mathrm{C}$ were comparable to the measured survival percentages at these temperatures. A similar approach has been used previously by Aitken et al. (2005). Figure 3 shows that at $22^{\circ} \mathrm{C}$ on Day 60 , survival was about $21.33 \%$, while at $32^{\circ}$ $\mathrm{C}$, survival was reduced to less than $1 \%$. Relatively, very fast inactivation was observed at $62^{\circ} \mathrm{C}$; the survival reached $0.16 \%$ on Day 4.

Using the inactivation kinetics we derived the temperature - time - survival relationship as follows.

$$
\mathrm{s}=100 \cdot \exp (-(a) \cdot \mathrm{t} \cdot \exp (-10217 / \mathrm{T}))
$$

where $\mathrm{s}$ is survival (\%); $a$ is constant $\left(=2.83 \times 10^{13}\right) ; t$ is the incubation time (day); and $T$ is temperature (K). Further solving Equation 3 provided an equation for $t$.

$$
\mathrm{t}=-3.5310^{-14} \cdot \ln (0.01 \cdot \mathrm{s}) / \exp (-10217 / \mathrm{T})
$$

Equation 4 can be used to calculate a required time for a given $s$ and $T$. It can be used to determine the required time for $E$. coli inactivation in anaerobic digesters treating dairy manure depending on temperature. In this study, we used filtered dairy manure for experiments, which may result in slightly different inactivation kinetics compared to unfiltered manure because of fiber and large solid manure particle presence. Those slight changes can be accounted for by adjusting $A$ in equation 2.

Descriptive statistics showing the impacts of temperature on total solid (TS), volatile solid (VS), $\mathrm{pH}$, ORP, biogas production, and methane contents are shown in Table 3. Impacts of temperatures in biogas production are shown in Figure 4 . At $52.5^{\circ} \mathrm{C}$, biogas production was relatively very quick (within 14 hours of incubation), while at 37 and $25^{\circ} \mathrm{C}$, onset of biogas was delayed until day 25 and 61, respectively. The cumulative biogas production at 37 and $25^{\circ} \mathrm{C}$, were 111 and $11 \mathrm{ml}$ over 41 and 61 days of incubation periods, respectively. The cumulative biogas production at $52.5^{\circ} \mathrm{C}(541.75 \mathrm{ml})$ was 4.8 and 49 times greater than that at 37 , and $25^{\circ} \mathrm{C}$. Methane content in biogas at $52.5^{\circ} \mathrm{C}$ varied between 44 and $70 \%$ with mean of $56 \pm 18 \%$, while at $37^{\circ} \mathrm{C}$, it varied from 26 to $55 \%$ with mean of $40.6 \pm 20.34$ (Table 3 ). Methane content at $25^{\circ} \mathrm{C}$ was not measured as biogas production was very low.

The variation in $\mathrm{pH}$ over incubation period is shown in Figure 5. At 37 and $25^{\circ} \mathrm{C}, \mathrm{pH}$ was reduced over time and both temperatures show similar patterns; however, at $52.5^{\circ} \mathrm{C}, \mathrm{pH}$ was increased (Table 3). The mean $\mathrm{pH}$ over incubation periods at $52.5,37$, and $25^{\circ} \mathrm{C}$, were 7.14 $\pm 0.25,6.82 \pm 0.29$, and $8.95 \pm 0.0 .70$, respectively. At $52.5^{\circ} \mathrm{C}, \mathrm{pH}$ was increased about $20.86 \%$, while at 37 and $25^{\circ} \mathrm{C}, \mathrm{pH}$ was decreased 11.70 and $8.78 \%$, respectively, at the end of incubation.

The impacts of temperatures on variation in VS/TS are shown in Figure 6. The reduction in VS/TS at 52.5 $\mathrm{C}$ was higher than that at 37 , and $25^{\circ} \mathrm{C}$. The initial VS/ TS ratio at 25,37 , and $52.5^{\circ} \mathrm{C}$ was $0.80,0.80$, and 0.73 , respectively. The reductions in VS/TS over incubation 
Table 1 Initial feedstock characteristics

\begin{tabular}{llllllll}
\hline Temperature & TS (\%) & VS (\%) & pH & TN (mg/l) & TP (mg/l) & TOC (mg/l) & E. coli (CFU/ml) \\
\hline $\begin{array}{l}\text { Moderate } \\
\left(25^{\circ} \mathrm{C}\right)\end{array}$ & 1.39 & 1.12 & 7.52 & 489 & 153 & 4500 & $6.5 \times 10^{7}$ \\
$\begin{array}{l}\text { Mesophilic } \\
\left(37^{\circ} \mathrm{C}\right)\end{array}$ & 2.05 & 1.25 & 7.40 & 390 & 333 & 4170 & $1.85 \times 10^{7}$ \\
$\begin{array}{l}\text { Thermophilic } \\
\left(52.5^{\circ} \mathrm{C}\right)\end{array}$ & 1.75 & 1.28 & 7.55 & 522 & 243 & 3900 & $2.5 \times 10^{7}$ \\
\hline
\end{tabular}

period were 39,11 , and $20 \%$, at 25,37 , and $52.5^{\circ} \mathrm{C}$, respectively. The liner regression lines for VS/TS changes over incubation period are shown in Figure 6. The descriptive statistics of total solid (TS) and volatile solid (VS) is shown in Table 3 . The TS and VS at $25^{\circ} \mathrm{C}$ was reduced approximately 29 and $57 \%$ at the end of incubation period. At $37^{\circ} \mathrm{C}$, TS and VS reduction was 38 and $46 \%$. At thermophilic temperature, TS and VS reduction was 53 and $63 \%$. At the beginning of incubation, ORP values, which indicates the redox potential, were $-300,-346,-288 \mathrm{mV}$, at 25,37 , and $52.5^{\circ} \mathrm{C}$, respectively. Over incubation period, ORP values varied from -353 to $14.70,-360$ to -150 , and -288 to $-10 \mathrm{mV}$, at 25 , $37,52.5^{\circ} \mathrm{C}$, respectively. The descriptive statics of ORP changes are shown in Table 3.

\section{Discussion}

Previous studies such as Aitken et al. (2005), and Popat et al. (2010) have used batch anaerobic digestion at thermophilic temperatures to understand temperatures' impact on pathogen inactivation and provided important information on biosolids' virus inactivation. The studies reported that inactivation rate increases with increasing temperature; however their studies were focused on thermophilic temperatures only. Our study focuses on understanding $E$. coli inactivation in dairy manure anaerobic digestion at a wide range of temperatures $\left(22-62^{\circ}\right.$ $C$; our results of $E$. coli inactivation are based on three different ranges of temperatures (moderate, mesophilic, and thermophilic).

Table 2 Summary of inactivation kinetics

\begin{tabular}{lllll}
\hline Temperature & $\boldsymbol{k}\left(\mathbf{d}^{-\mathbf{1}}\right)$ & ${ }^{\mathbf{a}} \boldsymbol{T}_{\boldsymbol{c}}$ (days) & ${ }^{\mathbf{b}} \boldsymbol{R}^{\mathbf{2}}$ & ${ }^{\mathbf{c}} \boldsymbol{D}_{\mathbf{1 0}}$ (days) \\
\hline $\begin{array}{l}\text { Low temp } \\
\left(25^{\circ} \mathrm{C}\right)\end{array}$ & 0.1177 & $>60$ & 0.81 & $9-10$ \\
$\begin{array}{l}\text { Mesophilic temp } \\
\left(37^{\circ} \mathrm{C}\right)\end{array}$ & 0.1335 & $>40$ & 0.94 & $7-8$ \\
$\begin{array}{l}\text { Thermophilic temp } \\
\left(52.5^{\circ} \mathrm{C}\right)\end{array}$ & 2.0069 & $<4$ & 0.93 & $<1$
\end{tabular}

${ }^{\text {a }} T_{c}$ is required time for "complete" inactivation (first sample in which $E$. coli concentration was below detection limit.

${ }^{\mathrm{b}} R^{2}$ values were obtained from liner regression between $\log _{10} E$. coli concentrations (CFU/ml) and incubation periods (days).

${ }^{c} D_{10}$ decimal reduction time (reduction of the population by one log-unit) corresponding to Figures $1 \mathrm{a}, 1 \mathrm{~b}$, and $1 \mathrm{c}$.
As shown in Figure $1 \mathrm{a}$ and $1 \mathrm{~b}$, the growths of $E$. coli was observed during initial phases. Initial growth spikes have also been reported by Smith et al. (2005) who studied the decay of E. coli NCTC 9001, E. coli O148 and E. coli $\mathrm{O} 158$ inoculated in $1.8 \mathrm{ml}$ tubes of culture broth. Smith et al. (2005) observed spikes in E. coli concentrations at $37^{\circ} \mathrm{C}$, but not at $55^{\circ} \mathrm{C}$. Aitken et al. (2005), and Popat et al. (2010), have studied initial temperature perturbation influence extensively. Initial perturbation occurs during inoculation, when a volume of liquid at a given temperature is inoculated with a volume of cooler liquid. Nolf (1932) reported a required time of $2-3$ minutes for the temperature of incubation mixture to reach the temperature of the water bath. In this study, for the moderate temperature experiment, the water temperature was unchanged, at mesophilic temperature, the water temperature went slightly below $37^{\circ} \mathrm{C}$ for about 2 minutes, and at thermophilic temperature, water temperature went slightly below $52.5^{\circ} \mathrm{C}$ for less than 2 minutes. We ignored these minor temperature variations in our analysis because the period of initial temperature perturbation was minimal compared to the total incubation period $(65,45$, and 29 days for moderate, mesophilic, and thermophilic, respectively).

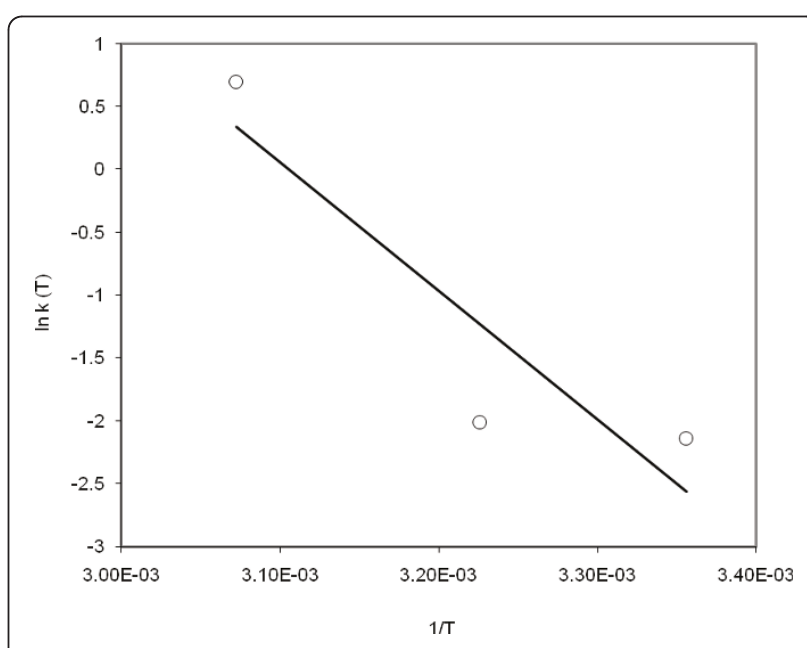

Figure 2 Arrhenius plot for $E$. coli inactivation over the temperatures 25,37 and $52.5^{\circ} \mathrm{C}$. The solid line indicates regression line, and hollow circles are inactivation rates of $E$. coli. 


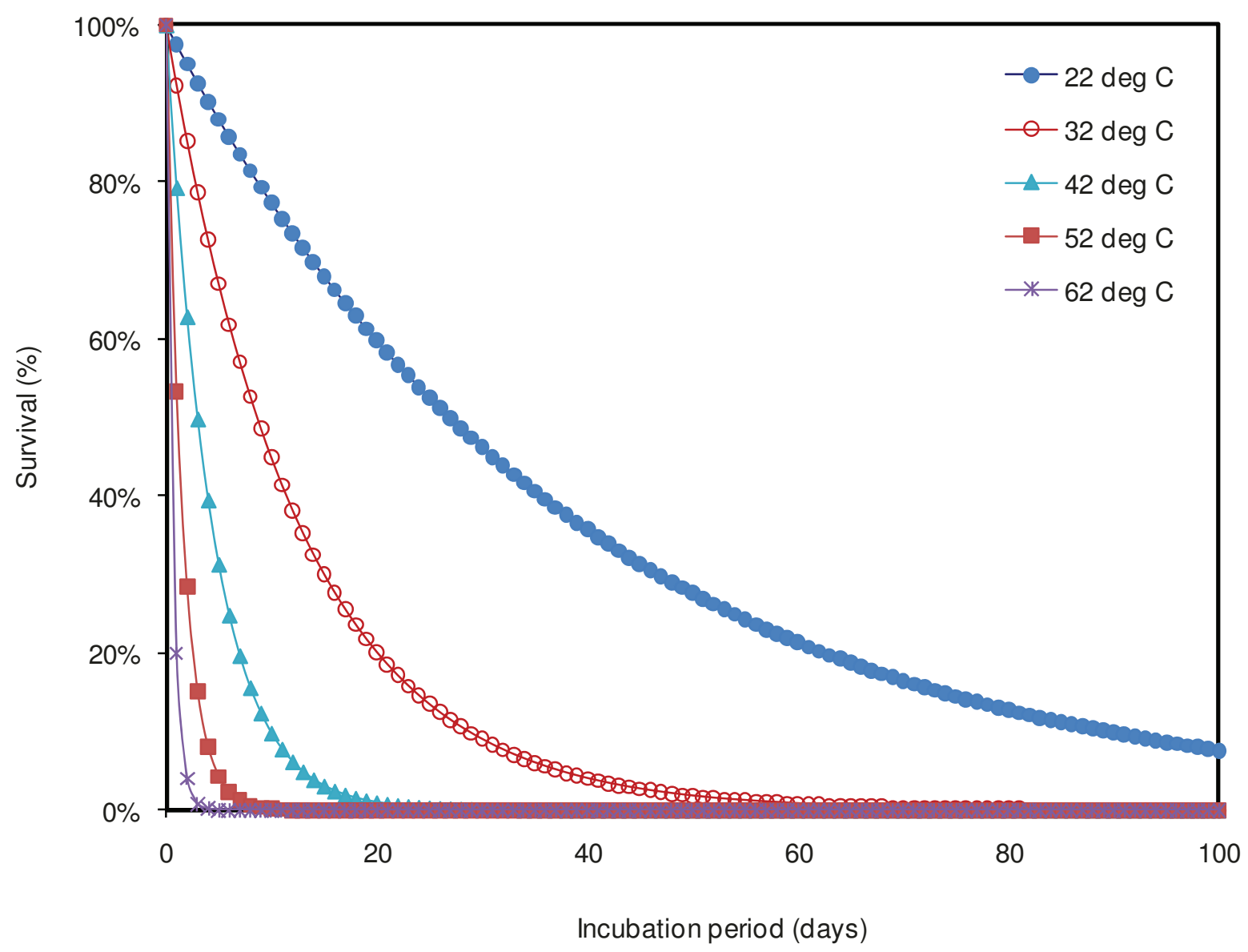

Figure 3 Survival percentages of $E$. coli over incubation period for temperature range $22-62^{\circ} \mathrm{C}$. The blue solid circles indicates survival percentage at $22^{\circ} \mathrm{C}$, red hollow circles is survival at $32^{\circ} \mathrm{C}$, aqua solid triangles is survival at $42^{\circ} \mathrm{C}$, red square at $52^{\circ} \mathrm{C}$, and purple crosses are survival at $62^{\circ} \mathrm{C}$.

Popat et al. (2010) reported inactivation energy of viruses of biosolids. For comparing our results, we were not able to find published reports; that have estimated inactivation energy of $E$. coli in dairy manure. Compared to Popat's study, who calculated inactivation energies of Ascaris suum and Poliovirus as of 105 and $39 \mathrm{~kJ} \mathrm{~mol}^{-1}$, respectively; our results are different. Another study by Aitken et al. (2005), have estimated inactivation energies of 580 and $550 \mathrm{~kJ} \mathrm{~mol}^{-1}$ for Ascaris suum and Poliovirus, respectively. Both studies estimated the inactivation energies in the thermophilic temperature range (49 $-56^{\circ} \mathrm{C}$ ); however, the differences in estimated inactivation energy is relatively large. The possible reason could be the differences in the sludge material used for incubations. While Aitiken et al. (2005) reported > $3 \log$ reduction of Ascaris within 30 minutes of incubation, Popat et al. (2010) reported two hours for the same reduction. Both studies speculated that such high activation energies are characteristics of protein denaturation, and therefore the primary inactivation mechanism at thermophilic temperatures could be capsid protein denaturation. The potential cause for the low inactivation energy values in our study could be either differences in types of measured pathogens or feedstock characteristics.

The effects of temperatures on E. coli inactivation are apparent (shown in Figures 1, 2, 3), however, inactivation can also be influenced by other factors such as ammonia, $\mathrm{pH}$, feedstock characteristics, volatile fatty acids, protein, fats, and carbohydrates. The impacts of these other factors in inactivation kinetics are unclear (Aitken et al. 2007,; Popat et al. 2010,). For sludge digestion it has been reported that the increased concentration of ammonia increases the inactivation of pathogenic viruses (Pecson et al. 2007,; Ward and Ashley 1977,). The presence of protective agents such as anionic detergents in sludge, reduces the inactivation (Ward and Ashley 1978,). Volatile fatty acids, which are produced by acidogenic bacteria during anaerobic digestion (Pandey et al. 2010,), enhance the inactivation rate 
Table 3 Changes in parameters over incubation period for different temperatures

\begin{tabular}{|c|c|c|c|c|c|c|c|}
\hline Temperatures & Initial & Final & Changes (\%) & Increase $(+) /$ decrease $(-)$ & Mean & Standard Deviation & ${ }^{\mathrm{d}}$ Range \\
\hline \multicolumn{8}{|c|}{ Total solids (TS) (\%) } \\
\hline${ }^{\mathrm{a}} 25^{\circ} \mathrm{C}$ & 1.39 & 0.99 & 29.06 & - & 1.37 & 0.18 & $0.99-1.67$ \\
\hline${ }^{b} 37^{\circ} \mathrm{C}$ & 2.05 & 1.25 & 38.96 & - & 1.58 & 0.20 & $1.25-2.05$ \\
\hline${ }^{\mathrm{c}} 52.5^{\circ} \mathrm{C}$ & 1.75 & 0.82 & 53.20 & - & 1.43 & 0.38 & $0.79-2.12$ \\
\hline \multicolumn{8}{|c|}{ Volatile solids (VS) (\%) } \\
\hline $25^{\circ} \mathrm{C}$ & 1.12 & 0.48 & 57.11 & - & 0.92 & 0.27 & $0.19-1.25$ \\
\hline $37^{\circ} \mathrm{C}$ & 1.65 & 0.89 & 45.84 & - & 1.21 & 0.19 & $0.89-1.65$ \\
\hline $52.5^{\circ} \mathrm{C}$ & 1.28 & 0.48 & 62.72 & - & 1.43 & 0.38 & $0.48-1.88$ \\
\hline \multicolumn{8}{|l|}{$\mathrm{pH}$} \\
\hline $25^{\circ} \mathrm{C}$ & 7.52 & 6.86 & 8.78 & - & 7.14 & 0.25 & $6.78-7.56$ \\
\hline $37^{\circ} \mathrm{C}$ & 7.40 & 6.53 & 11.70 & - & 6.82 & 0.29 & $6.34-7.40$ \\
\hline $52.5^{\circ} \mathrm{C}$ & 7.55 & 9.54 & 20.86 & + & 8.95 & 0.70 & $7.55-9.70$ \\
\hline \multicolumn{8}{|l|}{$\mathrm{ORP}(\mathrm{mV})$} \\
\hline $25^{\circ} \mathrm{C}$ & -300 & -90 & & + & -229 & 124 & $-353-14.70$ \\
\hline $37^{\circ} \mathrm{C}$ & -346 & -150 & & + & -314 & 44 & -360 to -150 \\
\hline $52.5^{\circ} \mathrm{C}$ & -288 & -20 & & + & -111 & 101 & -288 to -10 \\
\hline \multicolumn{8}{|c|}{ Biogas (ml); methane (\%) } \\
\hline $25^{\circ} \mathrm{C}$ & 0 & 0 & & & $0.34 ; N D$ & 1.42; ND & $0-5 ; N D$ \\
\hline $37^{\circ} \mathrm{C}$ & 0 & 0 & & & $4.4 ; 40.6$ & $8.1 ; 20.34$ & $0-30 ; 26-55$ \\
\hline $52.5^{\circ} \mathrm{C}$ & 0 & 0 & & & $18 ; 56$ & $22 ; 18$ & $0-87 ; 44-70$ \\
\hline
\end{tabular}

${ }^{a}$ incubation period $=61$ days; ${ }^{b}$ incubation period $=41$ days; ${ }^{c}$ incubation period $=28$ days; ${ }^{b}$ Range $=$ minimum - maximum; ND $=$ not detected

(Popat et al. 2010,). Collagen, a main protein of connective tissues in animals, significantly reduces the rate of virus inactivation (Milo 1971,). Pecson et al. (2007) stated that $\mathrm{pH}$ effects are not significant; however, the authors have also reported that $\mathrm{pH}$ influence cannot be separated from ammonia concentration and temperature, and the temperature effects are dominant.

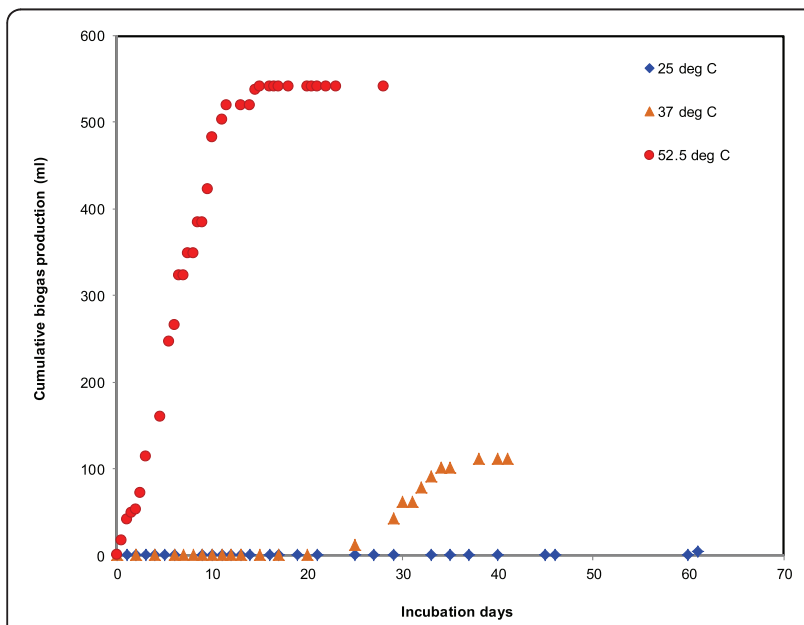

Figure $\mathbf{4}$ Impacts of temperatures on biogas production. The red solid circle indicates cumulative biogas production at $52.5^{\circ} \mathrm{C}$, yellow triangles indicate biogas production at $37^{\circ} \mathrm{C}$, and dark blue diamonds indicate biogas production at $25^{\circ} \mathrm{C}$.
The initial characteristics of the feedstock often differ among treatment facilities, and therefore, the reported inactivation kinetics should be applied with caution. For example, Aitken et al. (2007) studied the inactivation of putative pathogenic E. coli O157:H7 and putative non pathogenic $E$. coli in dairy cattle manure, and reported a mean inactivation coefficient, $k$, of $0.25 \mathrm{~min}^{-1}$ and 0.23

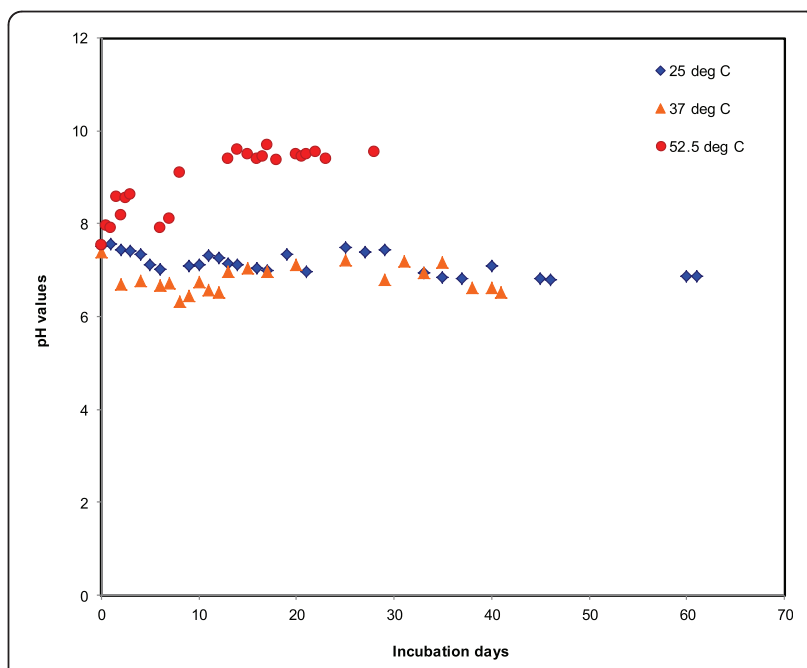

Figure $\mathbf{5}$ Impacts of temperatures on $\mathbf{p H}$ changes. The red solid red circle indicates $\mathrm{pH}$ changes at $52.5^{\circ} \mathrm{C}$, yellow triangles indicate $\mathrm{pH}$ changes at $37^{\circ} \mathrm{C}$, and dark blue diamonds indicate $\mathrm{pH}$ changes at $25^{\circ} \mathrm{C}$. 


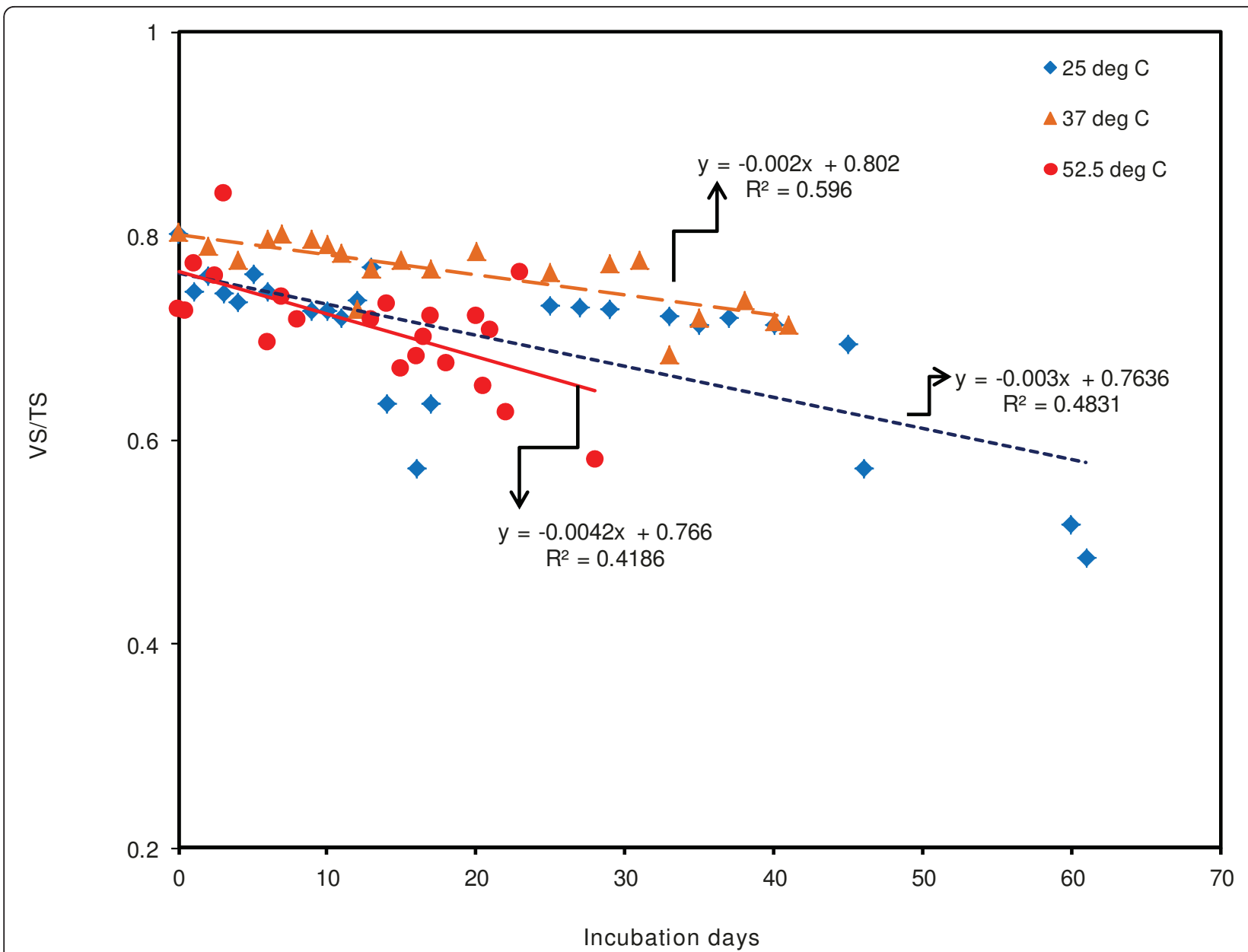

Figure 6 Impacts of temperatures on changes in ratio between VS and TS (VS/TS). The red solid line indicate regression line, and red circle indicated VS/TS reductions at $52.5^{\circ} \mathrm{C}$; the yellow long dash line indicates regression line, and yellow triangles indicate VS/TS at $37^{\circ} \mathrm{C}$; the blue short dash line indicates regression line, and the blue diamond indicate VS/TS at $25^{\circ} \mathrm{C}$.

$\min ^{-1}$ for pathogenic and non-pathogenic E. coli, respectively at $55^{\circ} \mathrm{C}$; and $0.034 \mathrm{~min}^{-1}$ and $0.018 \mathrm{~min}^{-1}$, respectively at $50^{\circ} \mathrm{C}$. In our study, we report an inactivation coefficient of $2.01 \mathrm{day}^{-1}\left(0.00139 \mathrm{~min}^{-1}\right)$ at $52.5^{\circ} \mathrm{C}$ for mixed wild strains of $E$. coli, which is significantly less. The possible reason for this discrepancy could be differences in the feedstock characteristics used for incubation or the heat resistance capacity of the E. coli strains used by Aitken et al. (2007).

Both experimental methods and tested pathogenic organisms can influence the results. Often the inactivation coefficients of pathogens are estimated in laboratories using either aqueous medium or biosolids or manure inoculated with pathogens. For example, inactivation kinetics calculated by Aitken et al. (2007),, Aitken et al. (2005),, and Popat et al. (2010); theses studies have determined inactivation kinetics by spiking a known concentration of pathogens into the feedstock, prior to anaerobic digestion. In our study, we enumerated the native
E. coli which were already present in dairy manure. The results can be more reliable, when native organisms are used in experiments. We tested $E$. coli because it is a popular indicator among researchers and recommended by the EPA (USEPA 2010,) for detecting the presence of faecal contamination and viruses in waters (Grisey et al. 2010,). Compared to reported time - temperature relationships used by the EPA, which calculates pathogen inactivation by extrapolating between two temperatures (Popat et al., 2010,), we used three different temperatures (moderate, mesophilic, and thermophilic) to calculate pathogen inactivation kinetics. Aitken et al. (2005), and Popat et al. (2010) have proposed to improving the EPA's time-temperature relationship as it neglects temperature mediated changes in deactivation mechanisms. The relationship we developed to estimate $E$. coli inactivation includes the temperature-mediated changes.

Besides impacts on $E$. coli inactivation, temperatures also influences changes in parameters such as $\mathrm{pH}$, TS, 
VS, ORP, biogas production, and methane contents. As shown in Table 3 and Figure 4, biogas production at thermophilic temperature was relatively very quick and high compared to mesophilic and moderate temperatures. This indicates that the anaerobic process was enhanced with increased temperatures, and thermophilic temperatures can be the best for increasing biogas production as well as for $E$. coli reduction. The methane content in biogas was also higher at thermophilic temperatures compared to moderate and mesophilic temperatures. Relatively higher VS and TS reduction were observed at thermophilic temperature within 28 days of incubation compared to 61 and 41 days of incubation at 25 and $37^{\circ} \mathrm{C}$. Other parameters, for example, ORP values indicated better reactor performance at the thermophilic temperature. At the higher temperature, negative ORP values were coincided with improved anaerobic digester performance; similar results, for example, negative ORP values with improved anaerobic digestion of food waste are reported by Kuo and Lai (2010). The high ORP indicates low redox potential, which can cause the low biogas production; methanogens, which produce biogas, are reported to be relatively more active at low ORP values.

In summary, we used moderate, mesophilic, and thermophilic temperatures to understand $E$. coli inactivation in anaerobic digestion of dairy manure. Besides E. coli inactivation, we also studied the impacts of temperatures on other parameters including, $\mathrm{pH}$, TS, VS, ORP, biogas production, and methane content. Results indicated that E. coli inactivation and biogas production greatly depend on temperatures and incubation period. At thermophilic temperature, E. coli inactivation and biogas production were faster than that of at moderate and mesophilic temperatures. We used this information to develop the model for predicting $E$. coli inactivation in anaerobic digestion of dairy manure and for developing the time -temperature - E. coli survival relationships. The relationships we proposed in Equations 3 and 4 can be used to understand $E$. coli inactivation in anaerobic digesters treating dairy manure.

\section{Acknowledgements}

Funding for this project was provided by lowa State University. The authors would like to thank Kendal Agee, Andrew Paxson, Charles Velasquez, and Ray Sims for assistance with sample collection and analysis.

\section{Competing interests}

The authors declare that they have no competing interests.

Received: 22 June 2011 Accepted: 15 July 2011 Published: 15 July 2011

\section{References}

Aitken MD, Sobsey MD, Blauth KE, Shehee M, Crunk PL, Walters GW (2005) Inactivation of Ascaris suum and Poliovirus in Biosolids under Thermophilic
Anaerobic Digestion Conditions. Environ Sci Technol 39:5804-5809. doi:10.1021/es048004h.

Aitken MD, Sobsey MD, Van Abel NA, Blauth KE, Singleton DR, Crunk PL, Nichols C, Walters GW, Schneider M (2007) Inactivation of Escherichia coli 0157:H7 during thermophilic anaerobic digestion of manure from dairy cattle. Water Res 4:1659-1666.

Alvarez R, Lidén G (2009) Low temperature anaerobic digestion of mixtures of llama, cow and sheep manure for improved methane production. Biomass Bioenerg 33:527-533. doi:10.1016/j.biombioe.2008.08.012.

Amin-Nayyeri M, Kianmehr MH, Arabhosseini A, Hassan-Beygi SR, Aghbashlo M (2010) Drying behavior and mathematical modeling of dairy cattle manure in a convective dryer. Appl Eng Agric 26:689-697.

American Public Health Association (APHA) (1999) Standard methods for the examination of water and wastewater. A.W.W.A., Water Environment Federation

Baert L, De Gusseme B, Boon N, Verstraete W, Debevere J, Uyttendaele M (2010) Inactivation of murine norovirus 1 and Bacteroides fragilis phage B40-8 by mesophilic and thermophilic anaerobic digestion of pig slurry. Appl Environ Microbiol: AEM 01657-09

Banu JR, Uan DK, Yeom IT (2009) Nutrient removal in an A2O-MBR reactor with sludge reduction. Bioresource Technol 100:3820-3824. doi:10.1016/j. biortech.2008.12.054.

Bortone G (2009) Integrated anaerobic/aerobic biological treatment for intensive swine production. Bioresource Technol 100:5424-5430. doi:10.1016/j. biortech.2008.12.005.

Brennan FP, O'Flaherty V, Kramers G, Grant J, Richards KG (2010) Long-Term Persistence and Leaching of Escherichia coli in Temperate Maritime Soils. Appl Environ Microbiol 76:1449-1455. doi:10.1128/AEM.02335-09.

Carrere H, Dumas C, Battimelli A, Batstone DJ, Delgenes JP, Steyer JP, Ferrer I (2010) Pretreatment methods to improve sludge anaerobic degradability: A review. J Hazard Mater 183:1-15. doi:10.1016/j.jhazmat.2010.06.129.

Climent M, Ferrer I, Baeza MD, Artola A, Vazquez F, Font X (2007) Effects of thermal and mechanical pretreatments of secondary sludge on biogas production under thermophilic conditions. Chem Eng J 133:335-342. doi:10.1016/j.cej.2007.02.020.

Côté C, Massé DI, Quessy S (2006) Reduction of indicator and pathogenic microorganisms by psychrophilic anaerobic digestion in swine slurries. Bioresorce Technology 97:686-691. doi:10.1016/j.biortech.2005.03.024.

Dumas C, Perez S, Paul E, Lefebvre X (2010) Combined thermophilic aerobic process and conventional anaerobic digestion: Effect on sludge biodegradation and methane production. Bioresource Technol 101:2629-2636. doi:10.1016/j.biortech.2009.10.065.

Farag M, Mohamed FA (1999) Effect of radiation processing as an integral part of the safe recycling animal waste. Anim Feed Sci Technol 77:267-280. doi:10.1016/S0377-8401(98)00252-1.

Forster-Carneiro T, Riau V, Pérez M (2010) Mesophilic anaerobic digestion of sewage sludge to obtain class B biosolids: Microbiological methods development. Biomass Bioenerg 34:1805-1812. doi:10.1016/j. biombioe.2010.07.010.

Gerba CP, Smith JE (2005) Sources of pathogenic microorganisms and their fate during land application of wastes. J Environ Qual 34:42-48

Gilroyed BH, Reuter T, Chu A, Hao X, Xu W, McAllister TA (2010) Anaerobic digestion of specified risk materials with cattle manure for biogas production. Bioresource Technol 101:5780-5785. doi:10.1016/j. biortech.2010.02.077.

Gong W, Li W, Liang H (2010) Application of A/O-MBR for treatment of digestate from anaerobic digestion of cow manure. J Chem Technol Biot 85:1334-1339. doi:10.1002/jctb.2437.

Grisey E, Belle E, Dat J, Mudry J, Aleya L (2010) Survival of pathogenic and indicator organisms in groundwater and landfill leachate through coupling bacterial enumeration with tracer tests. Desalination 261:162-168. doi:10.1016/j.desal.2010.05.007.

He YF, Pang YZ, Liu YP, Li XJ, Wang KS (2008) Physicochemical characterization of rice straw pretreated with sodium hydroxide in the solid state for enhancing biogas production. Energ Fuel 22:2775-2781. doi:10.1021/ ef8000967.

Jin Y, Hu ZH, Wen ZY (2009) Enhancing anaerobic digestibility and phosphorus recovery of dairy manure through microwave-based thermochemical pretreatment. Water Res 43:3493-3502. doi:10.1016/j.watres.2009.05.017. 
Kim D-H, Jeong E, Oh S-E, Shin HS (2010) Combined (alkaline + ultrasonic) pretreatment effect on sewage sludge disintegration. Water Res 44:3093-3100. doi:10.1016/j.watres.2010.02.032.

Klein M, Brown L, van den Akker B, Peters GM, Stuetz RM, Roser DJ (2010) Monitoring bacterial indicators and pathogens in cattle feedlot waste by real-time PCR. Water Res 44:1381-1388. doi:10.1016/j.watres.2009.11.016.

Kuo Wen-Chien , Lai Wen-Lung (2010) Treatment of kitchen waste using a mobile thermophilic anaerobic digestion system, Renew Energy, 35:2335-2339. doi:10.1016/.j.renene.2010.02.014.

Lang NL, Smith SR (2008) Time and temperature inactivation kinetics of enteric bacteria relevant to sewage sludge treatment processes for agricultural use. Water Res 42:2229-2241. doi:10.1016/j.watres.2007.12.001.

Létourneau V, Duchaine C, Côté C, Letellier A, Topp E, Massé D (2010) Presence of zoonotic pathogens in physico-chemically characterized manures from hog finishing houses using different production systems. Bioresource Technol 101:4048-4055. doi:10.1016/j.biortech.2010.01.009.

Maeda K, Hanajima D, Morioka R, Osada T (2010) Characterization and spatial distribution of bacterial communities within passively aerated cattle manure composting piles. Bioresource Technol 101:9631-9637. doi:10.1016/j. biortech.2010.07.057.

Massé D, Gilbert Y, Topp E (2010) Pathogen removal in farm-scale psychrophilic anaerobic digesters processing swine manure. Bioresource Technol In Press Corrected Proof.

Mawdsley JL, Bardgett RD, Merry RJ, Pain BF, Theodorou MK (1995) Pathogens in livestock waste, their potential for movement through soil and environmental-pollution. Appl Soil Ecol 2:1-15. doi:10.1016/0929-1393(94) 00039-A.

Milo GE (1971) Thermal inactivation of poliovirus in presence of selective organic molecules(cholestrol, Lecithin, Collagen, and Beta-carotene). Appl Environ Microbiol 21:198-202

Murphy RY, Duncan LK, Johnson ER, Davis MD, Smith JN (2002) Thermal inactivation D- and z-Values of Salmonella Serotypes and Listeria innocua in chicken patties, chicken tenders, franks, beef patties, and blended beef and turkey patties. J Food Prot 65:53-60

Nolf LO (1932) Experimental studies on certain factors influencing the development and viability of the ova of the human trichuris as compared with those of the human ascaris. Am J Epidemiol 16:288-322

Novak JT, Banjade S, Murthy SN (2010) Combined anaerobic and aerobic digestion for increased solids reduction and nitrogen removal. Water Res In Press Corrected Proof.

Pandey PK, Ndegwa PM, Alldredge JR, Pitts M, Soupir ML (2010) Modeling effects of granules on the start-up of anaerobic digestion of dairy wastewater with Langmuir and extended Freundlich equations. Bioproc Biosyst Eng 33:833-845. doi:10.1007/s00449-010-0406-x.

Pandey PK, Ndegwa PM, Soupir ML, Alldredge JR, Pitts M (2011) Efficacies of inocula on the startup of anaerobic reactors treating dariy manure under stirred and unstirred conditions. Biomass Bioenerg 35:2705-2720. doi:10.1016/j.biombioe.2011.03.017

Pecson BM, Barrios JA, Jiménez BE, Nelson KL (2007) The effects of temperature, $\mathrm{pH}$, and ammonia concentration on the inactivation of Ascaris eggs in sewage sludge. Water Res 41:2893-2902. doi:10.1016/j.watres.2007.03.040.

Pell AN (1997) Manure and Microbes: Public and Animal Health Problem? J Dairy Sci 80:2673-2681. doi:10.3168/jds.S0022-0302(97)76227-1.

Popat SC, Yates MV, Deshusses MA (2010) Kinetics of inactivation of indicator pathogens during thermophilic anaerobic digestion. Water Res 44:5965-5972. doi:10.1016/j.watres.2010.07.045.

Prapaspongsa T, Poulsen TG, Hansen JA, Christensen P (2010) Energy production, nutrient recovery and greenhouse gas emission potentials from integrated pig manure management systems. Waste Manage Res 28:411-422. doi:10.1177/0734242X09338728.

Puchajda B, Oleszkiewicz J, Sparling R, Reimers R (2006) Low-temperature inactivation of fecal coliforms in sludge digestion. Water Environ Res 78:680-685. doi:10.2175/106143006X101638.

Riau V, De la Rubia MÁ, Pérez M (2010) Temperature-phased anaerobic digestion (TPAD) to obtain class A biosolids: A semi-continuous study. Bioresource Technol 101:2706-2712. doi:10.1016/j.biortech.2009.11.101.

Rubio-Loza LA, Noyola A (2010) Two-phase (acidogenic-methanogenic) anaerobic thermophilic/mesophilic digestion system for producing Class A biosolids from municipal sludge. Bioresource Technol 101:576-585. doi:10.1016/j.biortech.2009.08.066.
Shen Y, Ren L, Li G, Chen T, Guo R (2010) Influence of aeration on CH4, N2O and $\mathrm{NH} 3$ emissions during aerobic composting of a chicken manure and high C/ $\mathrm{N}$ waste mixture. Waste Manage 31:33-38

Shepherd Jr MW, Singh R, Kim J, Jiang X (2010) Effect of heat-shock treatment on the survival of Escherichia coli 0157:H7 and Salmonella enterica Typhimurium in dairy manure co-composted with vegetable wastes under field conditions. Bioresource Technol 101:5407-5413. doi:10.1016/j. biortech.2010.01.147.

Shin SG, Lee S, Lee C, Hwang K, Hwang S (2010) Qualitative and quantitative assessment of microbial community in batch anaerobic digestion of secondary sludge. Bioresource Technol 101:9461-9470. doi:10.1016/j. biortech.2010.07.081.

Sinton L, Hall C, Braithwaite R (2007) Sunlight inactivation of Campylobacter jejuni and Salmonella enterica, compared with Escherichia coli, in seawater and river water. J Water Health 5:357-365. doi:10.2166/wh.2007.031.

Smith SR, Lang NL, Cheung KHM, Spanoudaki K (2005) Factors controlling pathogen destruction during anaerobic digestion of biowastes. Waste Manage 25:417-425. doi:10.1016/j.wasman.2005.02.010.

Soupir M, Mostaghimi S, Yagow E, Hagedorn C, Vaughan D (2006) Transport of fecal bacteria from poultry litter and cattle manures applied to pastureland. Water, Air, Soil Pollut 169:125-136. doi:10.1007/s11270-006-1808-x.

Sung S, Santha H (2003) Performance of temperature-phased anaerobic digestion (TPAD) system treating dairy cattle wastes. Water Res 37:1628-1636. doi:10.1016/S0043-1354(02)00498-0.

Tyrrel SF, Quinton JN (2003) Overland flow transport of pathogens from agricultural land receiving faecal wastes. J Appl Microbiol 94:87-93. doi:10.1046/j.1365-2672.94.s1.10.x.

Unc A, Goss MJ (2004) Transport of bacteria from manure and protection of water resources. Applied Soil Ecol 25:1-18. doi:10.1016/j.apsoil.2003.08.007.

United States Environmental Protection Agency (USEPA) (2010) Watershed assessment, Tracking \& Environmental Results. Washington, DC, U.S.

United States Census Bureau (2010) 2010 Statistical Abstract. Washington, DC, U. S.

Wagner AO, Malin C, Gstraunthaler G, IIImer P (2009) Survival of selected pathogens in diluted sludge of a thermophilic waste treatment plant and in $\mathrm{NaCl}-$-solution under aerobic and anaerobic conditions. Waste Manage 29:425-429. doi:10.1016/j.wasman.2008.03.003.

Wang L, Li YC, Chen P, Min M, Chen YF, Zhu J, Ruan RR (2010) Anaerobic digested dairy manure as a nutrient supplement for cultivation of oil-rich green microalgae Chlorella sp. Bioresource Technol 101:2623-2628. doi:10.1016/j.biortech.2009.10.062.

Ward RL, Ashley CS (1977) Identification of virucidal agent in wastewater-sludge. Applied and Environmental Microbiology 33:860-864

Ward RL, Ashley CS (1978) Identification of detergents as components of wastewater-sludge that modify thermal-stability of reovirus and enteroviruses. Appl Environ Microbiol 36:889-897

World Health Organization (WHO) (2010) Water Sanitation and Health. Geneva, Switzerland

Yilmaz V, Demirer GN (2008) Enhancing the performance of anaerobic digestion of dairy manure through phase-separation. Clean-Soil Air Water 36:760-766. doi:10.1002/clen.200800024.

Zaher U, Frear C, Pandey P, Chen S (2008) Evaluation of a new fixed-bed digester design utilizing large media for flush dairy manure treatment. Bioresource Technol 99:8619-8625. doi:10.1016/j.biortech.2008.04.034.

Ziemer CJ, Bonner JM, Cole D, Vinje J, Constantini V, Goyal S, Gramer M, Mackie R, Meng XJ, Myers G, Saif $L$ (2010) Fate and transport of zoonotic, bacterial, viral, and parasitic pathogens during swine manure treatment, storage, and land application. J Anim Sci 2009-2331

doi:10.1186/2191-0855-1-18

Cite this article as: Pandey and Soupir: Escherichia coli inactivation kinetics in anaerobic digestion of dairy manure under moderate, mesophilic and thermophilic temperatures. AMB Express 2011 1:18. 